Journal of Agricultural Sciences
(Tarim Bilimleri Dergisi)

\title{
Effects of Honey Bee Race and Season on Propolis Composition
}

\author{
Meral KEKEÇOĞLU ${ }^{a, b *} \mathbb{D}$, Merve KESKIN ${ }^{\mathbb{D}}$, Ceren BIRINCI ${ }^{d} \mathbb{D}$, Esra BIRINCI $^{d} \mathbb{D}$, Sevgi KOLAYLI $^{d} \mathbb{D}$ \\ ${ }^{a}$ Department of Biology, Faculty of Art and Science, Duzce University, 81620, Düzce, TURKEY

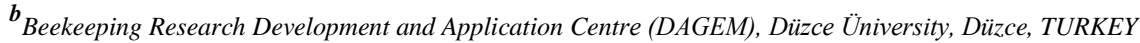 \\ ${ }^{c}$ Vocational School of Health Services, Bilecik Şeyh Edebali University, Bilecik, TURKEY \\ ${ }^{d}$ Department of Chemistry, Faculty of Science, Karadeniz Technical University, Trabzon, TURKEY
}

ARTICLE INFO

Research Article

Corresponding Author: Meral KEKECOĞLU, E-mail: meralkekecoglu@duzce.edu.tr

Received: 13 September 2019 / Revised: 17 March 2020 / Accepted: 19 March 2020 / Online: 04 September 2021

\section{ABSTRACT}

Honey bees collect the main material of propolis from the buds, leaves, branches, and barks or other botanical sources and mixed that resinous material with beeswax produced from abdominal exocrine glands, mandibular gland secretions, and pollen to produce propolis. The composition of propolis changes depends on multiple factors such as honey bee races, geographical locations, phytogeography, harvesting seasons, extraction methods and solvents. In this study, two different studies were conducted in two different locations in order to reveal the effect of race and season variables on the composition and antioxidant value of propolis. The effect of race factor was studied on three different

Keywords: Antioxidant capacity, Honey bee races, Phenolic compounds honey bee races (Apis mellifera caucasica, Apis mellifera syriaca and Apis mellifera carnica) and two different ecotypes (Muğla ecotype and Yığılca ecotype) to investigate the effects of race factor on propolis composition in Central Anatolia by under the controlled conditions. The effect of seasonal change was determined by Yı̆ğlca ecotype of $A$. melifera anatoliaca in the apiary located in Yiğılca, Düzce location. Studied samples were harvested by propolis trap between May and October. Total phenolic content, total antioxidant capacity and chemical profiles of propolis samples were determined using HPLC-UV. The obtained results showed that honey bee race and season have an effect on the antioxidant capacity and chemical composition of propolis.

(C) Ankara University, Faculty of Agriculture

\section{Introduction}

Propolis is a resinous, waxy substance collected by honey bees from the trees, and other plant sources. It is used as a sealant and antimicrobial agent inside the hive. Moreover, it has gained popularity as a natural health product, used extensively in the food industry as supplementary food to improve human health and prevent disease (Eroglu et al. 2008; Ozkul et al. 2005; Uzel et al. 2005). Propolis contains biological active compounds like phenolics. Unfortunately, the chemical composition of propolis varies depending on the plant material, geographical origin, honey bee subspecies and harvest season (Bankova et al. 2006; Miguel et al. 2011).

There are 27 honey bee races that have been identified all over the world. Five honey bee races (Apis melifera caucasica, A. m. syriaca, A. m. anatoliaca, A. m. meda, A. m. carnica) distributes in Turkey due to its special geographical location on the migration routes and climatic range (Ruttner 1988). A. mellifera races adapted to the climatic conditions and floral structure of the regions where they spread on. It has been known that these adaptations have an effect on morphological and physiological structure of the honey bees and it may result as different races and ecotypes. These adaptations of different races can also affect the glands sizes and secretions, also it connectedly affects the composition and activity of the honey bee products such as propolis and royal jelly, which produces by or mixing with honey bees secretions (Silici \& Kutluca 2005, Bankova et al. 2006; Miguel et al. 2011). Al-Ghamdi et al. (2011) were compared the development of hypopharyngeal glands (HPG) of Apis mellifera jemenitica and Carniolan hybrid bees. They detected the staining of cell cytoplasm by hematoxylin and eosin as similar but, secretory cell numbers were found more in Carniolan hybrid than the A. m. jemenitica. Even though all these findings, there is limited study found for honey bee race effect on propolis compound. Brazilian green and red propolis originating from Africanised A. mellifera is rich in prenylated phenylpropanoids and isoflavonoids, respectively (Teixeira et al. 2005; Daugsch et al. 2008). C-methylated flavanones, terpenic acids and phenolic acids such as gallic acid and diterpenic acids, the p-coumaric and abietic types are the predominant chemicals in the cerumen propolis from stingless bees, but it lacks the characteristic flavonoids and prenylated phenolics found in propolis from other honey bee species in Australia (Massaro et al. 2011; Massaro et al. 2014).

In present study, two different research were conducted in two different regions to reveal the effect of season and race factors on the propolis content. (1) Race factor: We investigated the effect of honey bee races and ecotypes which distribute in Turkey, 
A. m. caucasica, A. m. syriaca, and A. m. carnica, Yı̆̆ılca ecotype and Muğla ecotype on propolis composition under the controlled conditions in central Anatolia, (2) Season factor: The effect of season on the composition of propolis collected by Yığılca ecotype were investigated in the Düzce University Beekeeping Research Development and Aplication Centre (DAGEM) apiary in Düzce, Turkey.

\section{Material and Methods}

\subsection{Propolis collection}

To determine the effect of the honey bee race and ecotypes of Apis mellifera L. on collected propolis composition we maintained three indigenous races (A. m. caucasica, A. m. syriaca, and A. m. carnica) and two ecotypes (Yığılca and Muğla) in the same apiary, under the controlled conditions in central Anatolia. 12 and 15 colonies were represented three honey bee races and two ecotypes in Central Anatolia (Yigilca ecotype ( $=15)$ A.m. caucasica $(\mathrm{N}=15)$, A. m. anatolica $(\mathrm{N}=13)$ A. $m$. syriaca $(\mathrm{N}=14)$ A. m. carnica $(\mathrm{N}=12))$. Propolis samples were collected three times from each colony.

In addition, the seasonal effect on the propolis phenolic composition was also investigated. Therefore, samples harvested in different seasons from May to October were examined to detect any variations in the chemical composition of the propolis collected from the same area and by the same honey bee ecotype habited in the DAGEM apiary in Düzce, Turkey.

Propolis samples were collected with propolis traps in the early spring season and samples were collected regularly every month from May to October 2016. The samples were stored in a deep freezer at $-20^{\circ} \mathrm{C}$ until further processing.

\subsection{Propolis extraction}

Methanolic propolis extracts were used for analyses. Approximately 3.0 g propolis was extracted with $99 \%$ methanol. The maceration technique was used for extraction. After $24 \mathrm{~h}$, the mixture was filtered and the final volume of the solution was adjusted with methanol.

\subsection{Determination of total phenolic content (TPC) and total flavonoids}

The TPCs of the methanol extracts were determined following the Folin-Ciocalteu method (Singleton et al., 1999). Gallic acid was used as a standard and the phenolic content was measured at $760 \mathrm{~nm}$. The amount of total flavonoid content was measured by the $\mathrm{AlCl}_{3}$ spectrophotometric method at $415 \mathrm{~nm}$, as reported previously (Fukumoto et al. 2000), using quercetin as the standard.

\subsection{Determination of total antioxidant capacity}

The total antioxidant capacity was determined by using ferric-tripyridyltriazine (Fe-III-TPTZ) complex (Benzie \& Strain 1996). Trolox was used as a positive control in order to construct a reference curve (62.5-1000 M). 2,2-diphenyl-1-picryl-hydrazyl (DPPH) free radical scavenging method (Molyneux 2004). The equal milliliter of propolis extracts and fresh DPPH solution was mixed and measured at $517 \mathrm{~nm}$ after 50 min using a spectrophotometer. The DPPH scavenging activity was calculated as $\mathrm{SC}_{50}$ (mg of sample per $\mathrm{mL}$ ), too.

\subsection{Determination of phenolic compounds by RP-HPLC-UV}

Fourteen standards of phenolic compounds were analysed using HPLC (Elite LaChromHitachi, Japan) with a UV-Vis detector. The phenolic profile was determined according to Can et al. (2015) using a Fortis C18 column $(150 \mathrm{~mm} \times 4.6 \mathrm{~mm}, 5 \mu \mathrm{m})$. The mobile phase consisted of (A) $2 \%$ acetic acid in water and (B) $70 \%$ acetonitrile in water. The injection volume of the samples was $20 \mu \mathrm{L}$ with the flow rate at $0.75 \mathrm{~mL} / \mathrm{min}$. The eluent was monitored at $280 \mathrm{~nm}$ at $30^{\circ} \mathrm{C}$. For quantitative determination, the calibration curves of each phenolic component were between 0.998 and 0.999 (Table 1). 
Table 1- RP-HPLC-UV validation parameters of the phenolic compounds

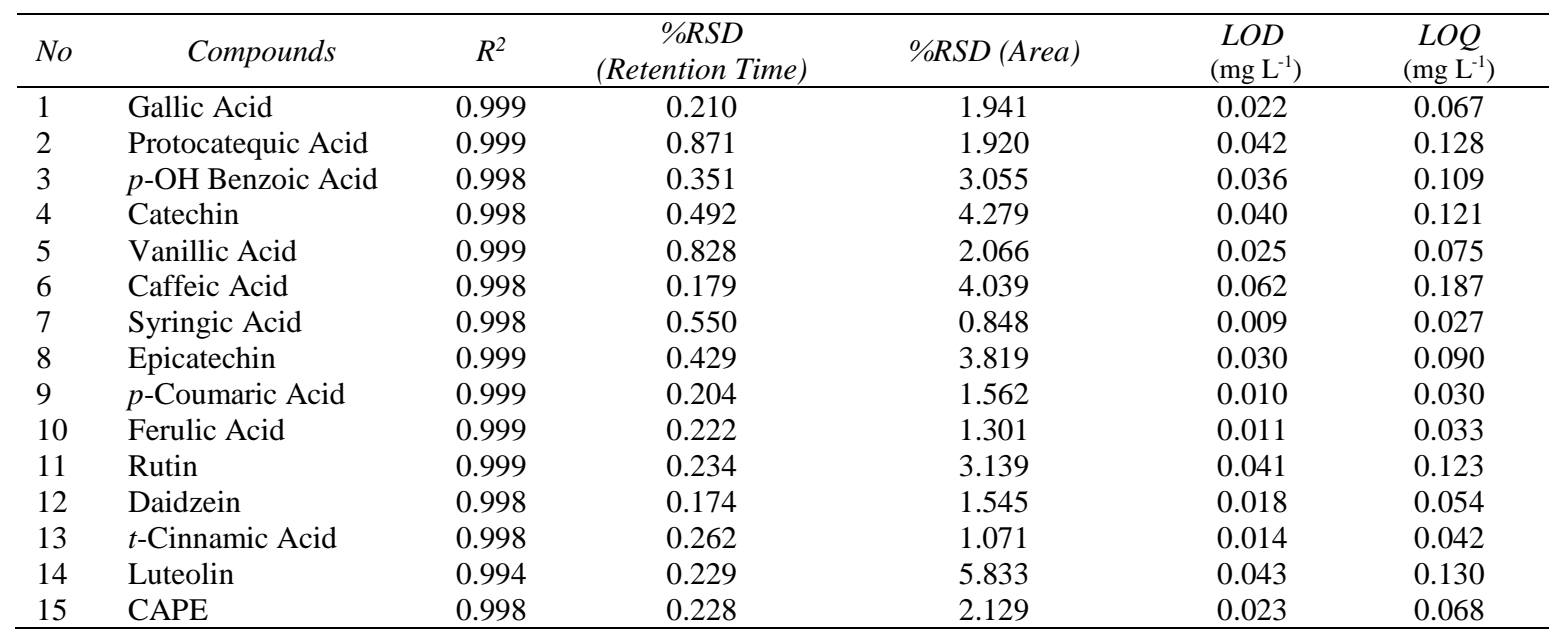

The analyses of the caffeic acid phenethyl ester (CAPE) compound was carried out using HPLC with UV-Vis detection (Elite LaChromHitachi, Japan) and a Fortis C18 column $(150 \mathrm{~mm} \times 4.6 \mathrm{~mm}, 5 \mu \mathrm{m})$. The mobile phase consisted of (A) $0.1 \%$ formic acid in water and (B) $0.1 \%$ formic acid in acetonitrile. The sample injection volume was $25 \mu \mathrm{L}$ at a flow rate of $1.0 \mathrm{~mL} / \mathrm{min}$, and the eluent was monitored at $270 \mathrm{~nm}$ at $30{ }^{\circ} \mathrm{C}$. The programmed solvent used began with a linear gradient held at $90 \% \mathrm{~A}$ for 3 min, decreasing to $70 \% \mathrm{~A}$ at $10 \mathrm{~min}, 50 \% \mathrm{~A}$ at $20 \mathrm{~min}, 10 \% \mathrm{~A}$ at $40 \mathrm{~min}, 40 \% \mathrm{~A}$ at $45 \mathrm{~min}$, and finally, $75 \% \mathrm{~A}$ at $50 \mathrm{~min}$.

\subsection{Statistical analyses}

The statistical analyses were performed using SPSS 15.0 software for Windows (SPSS Inc., Chicago, IL, USA). Data were expressed as mean \pm SE. One-way variance analysis (ANOVA) and the Tukey test were used for differences regarding the honey bee race and season with $\mathrm{P}<0.05$ considered as statistically significant.

\section{Results and Discussion}

The aim of the present study was to detect the effect of season and race factors on propolis phenolic content, chemical compositions and antioxidant value. To identify the race effect, propolis samples were gathered in the central Anatolia region of Turkey and variants such as plant material and harvest time were kept constant. Total phenolic and total flavonoid contents were found to vary according to the honey bee races. The propolis samples of the Yiğılca honey bee colonies contained the highest phenolic content $\left(18.24 \pm 0.56 \mathrm{mg} \mathrm{GAE} . \mathrm{g}^{-1}\right)$, followed by Apis mellifera syriaca propolis $\left(16.92 \pm 0.40 \mathrm{mg}\right.$ GAE. $\left.\mathrm{g}^{-1}\right)$. Total flavonoid content was found to be the highest in the $A$. $m$. syriaca propolis samples $\left(8.60 \pm 3.80 \mathrm{mgQE} . \mathrm{g}^{-1}\right)$, whereas propolis of Muğla honey bee ecotype contained the lowest phenolic content $\left(4.25 \pm 0.55 \mathrm{mg}\right.$ GAE. $\left.\mathrm{g}^{-1}\right)$. The highest antioxidant capacity (FRAP) was detected in the A. m. syriaca propolis samples $\left(2125 \pm 86.20 \mathrm{FeSO}_{4} .7 \mathrm{H}_{2} \mathrm{O} \mu \mathrm{l} \mathrm{moL.g}{ }^{-1}\right)$ and lowest value detected in the Muğla ecotype $\left(1442 \pm 20.50 \mathrm{FeSO}_{4} \cdot 7 \mathrm{H}_{2} \mathrm{O} \mu \mathrm{l}\right.$ moL.g $\left.{ }^{-1}\right)$. The radical scavenging activity showed different ranking, while the highest score detected in Muğla ecotype $\left(0.40 \pm 0.18\left(\mu \mathrm{g} \cdot \mathrm{mL}^{-1}\right)\right.$, the lowest score found in Yiğglca $\left(0.05 \pm 0.09 \mu \mathrm{g} . \mathrm{mL}^{-1}\right)$ and $A . m$. syriaca $\left(0.06 \pm 0.02 \mu \mathrm{g} \cdot \mathrm{mL}^{-1}\right)$ respectively (Table 2$)$.

Table 2- The effect of honey bee races on total phenolics and antioxidant values

\begin{tabular}{lccccc}
\hline Parameters & Muğla ecotype & A. m. caucasica & A. m. carnica & Yiğllca ecotype & A. m. syriaca \\
\hline $\begin{array}{l}\text { Total phenol contents } \\
\left(\mathrm{mg} \mathrm{GAE.g}^{-1}\right)\end{array}$ & $12.50 \pm 0.33^{\mathrm{a}}$ & $13.25 \pm 1.54^{\mathrm{a}}$ & $12.31 \pm 0.14^{\mathrm{a}}$ & $18.24 \pm 0.56^{\mathrm{b}}$ & $16.92 \pm 0.40^{\mathrm{b}}$ \\
\hline $\begin{array}{l}\text { Total flavonoids } \\
(\mathrm{mg} \mathrm{QE.g}\end{array}$ & $\left.4.25 \pm 0.55^{\mathrm{a}}\right)$ & $5.41 \pm 0.65^{\mathrm{b}}$ & $4.85 \pm 2.44^{\mathrm{c}}$ & $5.30 \pm 1.56^{\mathrm{d}}$ & $8.60 \pm 3.80^{\mathrm{e}}$ \\
\hline $\begin{array}{l}\text { FRAP } \\
\left(\mathrm{FeSO} 4.7 \mathrm{H}_{2} \mathrm{O} \mu 1 \mathrm{mol.g} \mathrm{g}^{-1}\right)\end{array}$ & $1442 \pm 20.50^{\mathrm{a}}$ & $1688 \pm 38.40^{\mathrm{b}}$ & $1960 \pm 120.30^{\mathrm{c}}$ & $1850 \pm 130.60^{\mathrm{c}}$ & $2125 \pm 86.20^{\mathrm{d}}$ \\
\hline $\begin{array}{l}\mathrm{DPPH} \\
\left(\mu \mathrm{g} . \mathrm{mL}^{-1}\right)\end{array}$ & $0.40 \pm 0.18^{\mathrm{c}}$ & $0.14 \pm 0.15^{\mathrm{b}}$ & $0.08 \pm 0.03^{\mathrm{a}}$ & $0.05 \pm 0.09^{\mathrm{a}}$ & $0.06 \pm 0.02^{\mathrm{a}}$ \\
\hline
\end{tabular}

FRAP: ferric reducing antioxidant power, DPPH: 2-diphenyl-1-picrylhydrazyl radical scavenging activity. The same letter is not significantly different $(\mathrm{P}<0.05)$

Phenolic composition of propolis samples collected by different honey bee races were compared. Gallic acid, proto-catechuic acid, p-OH benzoic acid weren't determined in propolis samples. Vanillic acid and catechin were determined only in propolis 
samples of Muğla ecotype. (Table 3). In the previous study, Vanillin was detected in A. m. anatoliaca and A. m. carnica propolis samples from the same apiary in Erzurum, though it was not found in Apis mellifera caucasica propolis samples (Silici \& Kutluca, 2005). Greenaway et al., (1987) determined vanillin and vanillic acid in England propolis but they did not report catechin in propolis samples. Similar with our findings, Eroğlu et. al. (2021) determined that honey bee races used neither the same nor the single propolis source. The plant choice differences of honey bee races affect the antioxidant value of the propolis samples due to the different ingredients of plants.

Table 3- Phenolic composition of propolis samples depend on honey bee races and ecotypes ( $\mu \mathrm{g}$ phenolic compound.g propolis sample ${ }^{-1}$ )

\begin{tabular}{|c|c|c|c|c|c|c|c|c|c|c|c|c|c|c|c|}
\hline $\begin{array}{l}\text { Races } \\
\mu g^{-1} g^{-1}\end{array}$ & $G a$ & $\begin{array}{c}\text { Proto } \\
\text { Cat }\end{array}$ & $\begin{array}{c}p-O H \\
B A\end{array}$ & Cat & $\mathrm{Va}$ & Caff & Syr & EpCa & $p-\mathrm{Cou}$ & $\mathrm{Fer}$ & $R u$ & Dai & $t$-Cinn & Lut & Cape \\
\hline A.m.caucasia & - & - & - & - & - & $\begin{array}{c}390.20 \\
\pm 22.30^{\mathrm{c}}\end{array}$ & - & $\begin{array}{c}190.30 \\
\pm 24.30^{\mathrm{a}}\end{array}$ & $\begin{array}{c}137.60 \\
\pm 33.60^{c}\end{array}$ & $\begin{array}{r}77.50 \\
\pm 3.36^{\mathrm{b}}\end{array}$ & - & - & $\begin{array}{c}7.08 \\
\pm 1.20^{\mathrm{b}} \\
\end{array}$ & $\begin{array}{c}2541 \\
\pm 15.46^{\mathrm{b}} \\
\end{array}$ & $\begin{array}{c}390.05 \\
\pm 32.30^{\text {ab }}\end{array}$ \\
\hline A.m.syriaca & - & - & - & - & - & $\begin{array}{c}85.60 \\
\pm 12.40^{\mathrm{a}}\end{array}$ & - & - & $\begin{array}{c}24.25 \\
\pm 5.77^{\mathrm{a}}\end{array}$ & $\begin{array}{c}381.82 \\
\pm 26.50^{c}\end{array}$ & - & $\begin{array}{c}17.2 \\
\pm 2.30^{\mathrm{b}}\end{array}$ & $\begin{array}{c}38.24 \\
\pm 5.06^{\mathrm{c}}\end{array}$ & $\begin{array}{c}11453 \\
\pm 23.88^{\mathrm{d}}\end{array}$ & $\begin{array}{c}818.52 \\
\pm 28.99^{c}\end{array}$ \\
\hline A.m.carnica & - & - & - & - & - & $\begin{array}{c}1013 \\
\pm 15.50^{\mathrm{d}}\end{array}$ & - & $\begin{array}{c}324.33 \\
\pm 16.05^{\mathrm{c}}\end{array}$ & $\begin{array}{c}291.30 \\
\pm 22.05^{\text {d }}\end{array}$ & $\begin{array}{c}10.23 \\
\pm 1.30^{\mathrm{a}}\end{array}$ & $\begin{array}{c}713.80 \\
\pm 56.30^{\mathrm{b}}\end{array}$ & $\begin{array}{c}5.66 \\
\pm 2.41^{\mathrm{a}}\end{array}$ & $\begin{array}{c}41.78 \\
\pm 5.33^{\mathrm{c}}\end{array}$ & $\begin{array}{c}4304 \\
\pm 28.05^{\mathrm{c}}\end{array}$ & $\begin{array}{l}291.60 \\
\pm 5.60^{\mathrm{a}}\end{array}$ \\
\hline Muğla ecotype & - & - & - & $\begin{array}{l}222.30 \\
\pm 13.40\end{array}$ & $\begin{array}{c}9.40 \\
\pm 0.20\end{array}$ & $\begin{array}{c}214.80 \\
\pm 30.06^{\mathrm{b}}\end{array}$ & - & $\begin{array}{c}253.62 \\
\pm 17.50^{\mathrm{b}}\end{array}$ & $\begin{array}{c}90.70 \\
\pm 20.30^{\mathrm{b}}\end{array}$ & $\begin{array}{c}17.03 \\
\pm 2.34^{\mathrm{a}}\end{array}$ & $\begin{array}{c}10.60 \\
\pm 1.40^{\mathrm{a}}\end{array}$ & - & $\begin{array}{c}2.45 \\
\pm 0.66^{\mathrm{a}}\end{array}$ & $\begin{array}{c}1497 \\
\pm 16.30^{\mathrm{a}}\end{array}$ & $\begin{array}{r}410.10 \\
\pm 20.02^{\mathrm{b}}\end{array}$ \\
\hline Ylgilca ecotype & e - & - & - & - & - & $\begin{array}{c}2086 \\
\pm 12.30^{\mathrm{e}}\end{array}$ & - & - & $\begin{array}{r}704.30 \\
\pm 23.33^{\mathrm{e}}\end{array}$ & $\begin{array}{c}18.60 \\
\pm 4.40^{\mathrm{a}}\end{array}$ & - & $\begin{array}{c}32.6 \\
\pm 4.60^{\mathrm{c}}\end{array}$ & $\begin{array}{c}57.40 \\
\pm 6.71^{\text {d }}\end{array}$ & $\begin{array}{c}4683 \\
\pm 38.60^{\mathrm{c}}\end{array}$ & $\begin{array}{c}211.23 \\
\pm 17.56^{\mathrm{a}}\end{array}$ \\
\hline
\end{tabular}

The same letter is not significantly different $(\mathrm{P}<0.05)$. Gallic acid $(\mathrm{Ga})$, proto-catechuic acid (ProtoCat), p-OH benzoic acid (p-OH BA), catechin $(\mathrm{Cat})$, vanillic acid (Va), caffeic acid (Caff), syringic acid (Syr), Epicatechin (EpCa), p-coumaric acid ( $p$-Cou), ferulic acid (Fer), rutin (Ru), daidzein (Dai)tcinnamic acid ( $t$-Cinn), luteolin (Lut) and caffeic acid phenethyl ester (Cape).

Honey bee race is one of the important variable for the propolis composition, due to the substances secreted (wax and saliva) and plant choice differences of honey bees (Gomez-Caravaca et al. 2006; Da Cunha et al. 2013; Wilson et al. 2013; Dutra et al. 2014; Silici \& Kutluca 2005). Race differences also have an effect on average propolis yield as stated in previous literature; highest to lowest respectively as; A. m. anatoliaca, A. m. ligustica, A. m. carnica, A. m. caucasica in literature (Kutluca 2003; Şahinler \& Gül 2005). Şahinler \& Gül (2005) compared bee races (Apis mellifera lingustica, Apis mellifera anatoliaca, Apis mellifera caucasica, Apis mellifera carnica) for propolis collection amounts and, they did not determine significant differences between the races, though highest propolis collection amount determined in Apis mellifera anatoliaca. In the later study, it was determined that A. m. carnica, Yığılca ecotype, A. m. caucasica which distributes on Northern Turkey have better propolis collecting ability than Muğla ecotype and A. m. syriaca which distribute on Southern of Turkey (Kekecoglu et al. 2020). Despite all this information, there is still limited study for honey bee race effect on propolis composition.

In addition to honey bee race, the effect of season on propolis composition was investigated. The total phenolic and flavonoid contents were significantly reduced between May+June and September+October $(\mathrm{P}<0.05)$. The highest phenolic and flavonoid values of the samples were found in the spring season as $27.29 \mathrm{mg} \mathrm{GAE} . \mathrm{g}^{-1}$ and $9.25 \mathrm{mgQE} . \mathrm{g}^{-1}$ respectively. The higher antioxidant capacities for the propolis samples observed in the spring season were reduced in summer and then increased again in autumn. The 2,2-diphenyl-1-picrylhydrazyl (DPPH) free radical scavenging activities showed parallel fluctuation with the flavonoid amounts in all season (Table 4).

Table 4- Seasonal Impact on total polyphenols content and antioxidant activity of propolis samples by the month

\begin{tabular}{lllll}
\hline Parameters & May+June & July+August & Sep+october & Mean values \\
\hline Total Phenolic contents $\left(m g\right.$ GAE.g $\left.{ }^{-1}\right)$ & $34.85 \pm 4.32^{\mathrm{c}}$ & $25.82 \pm 3.08^{\mathrm{b}}$ & $21.26 \pm 2.4^{\mathrm{a}}$ & $27.29 \pm 1.2$ \\
Total flavonoids $\left(\mathrm{mgQE} . \mathrm{g}^{-1}\right)$ & $9.25 \pm 1.02^{\mathrm{b}}$ & $4.91 \pm 0.60^{\mathrm{a}}$ & $5.37 \pm 0.7^{\mathrm{a}}$ & $6.51 \pm 0.52$ \\
FRAP $\left(\mathrm{FeSO} 4.7 \mathrm{H}_{2} \mathrm{O} \mu \mathrm{l} \mathrm{moL} \cdot \mathrm{g}^{-1}\right)$ & $2861 \pm 12,56^{\mathrm{c}}$ & $2117.55 \pm 55.5^{\mathrm{a}}$ & $2668.66 \pm 20,40^{\mathrm{b}}$ & $2548.88 \pm 11$ \\
DPPH $\left(\mu \mathrm{g} . \mathrm{mL}^{-1}\right)$ & $0.02 \pm 0.0^{\mathrm{a}}$ & $0.03 \pm 0.0^{\mathrm{a}}$ & $0.03 \pm 0.0^{\mathrm{a}}$ & $0.04 \pm 0.0$ \\
\hline
\end{tabular}

FRAP: ferric reducing antioxidant power, DPPH: 2-diphenyl-1-picrylhydrazyl radical scavenging activity, $\mathrm{n}=45$ for each season. The same letter is not significantly different $(\mathrm{P}<0.05)$

The composition of propolis from sources within short distances of each other in the same region can dramatically differ due to plant diversity and the limited travel distance of the bees from the propolis collection field to the place of deposition (Marcucci 1995). The results of the present study showed that propolis samples collected from May to October had unstable compositions due to the changing seasonal flora. In the Düzce region, the richest phenolic compounds were found in the early spring season (May+June). The antioxidant capacity of the propolis samples was also found to be higher in May+June than in the other seasons. The high phenolic content of the propolis samples may be explained by the plants accessible in the region during the spring period. As with the phenolic content, total antioxidant capacity and DPPH radical scavenging activity were found to be higher 
in the May+June season than at other harvest times. In most cases, the higher phenolic content cause higher antioxidant activity, as well as an antimicrobial and anti-inflammatory activities (Can et al. 2015; Baltas et al. 2016).

When the propolis phenolic profiles were examined according to the collection time, some differences were observed among the months. Except for the proto-catechuic acid, and p-OH benzoic acid, all the phenolic compounds were detected in propolis samples harvested in the spring and summer seasons. Surprisingly, CAPE was detected in all propolis samples harvested in all season. Although some phenolic components were at high levels in May+June, some were found to be lower. Gallic acid and catechin were detected in May+June, but not in September+October, while daidzein was not detected in May+June (Table 5).

Table 5- Effect of seasonal changes of phenolic profile collected from Düzce by Yıgılca honey bee ecotype ( $\mu \mathrm{g}$ phenolic compound.g propolis sample ${ }^{-1}$ )

\begin{tabular}{|c|c|c|c|c|c|c|c|c|c|c|c|c|c|c|c|}
\hline $\begin{array}{l}\text { Seasons } \\
\mu g . g^{-1}\end{array}$ & $G a$ & $\begin{array}{c}\text { Proto } \\
\text { Cat }\end{array}$ & $\begin{array}{c}p-O H \\
B A\end{array}$ & Cat & $V a$ & Caff & Syr & EpCa & $p$-Cou & Fer & $R u$ & Dai & t-Cinn & Lut & Cape \\
\hline May+June & $\begin{array}{c}13.30 \\
\pm 2.35^{\text {a }}\end{array}$ & - & - & $\begin{array}{c}1.23 \\
\pm 0.52 \\
\end{array}$ & $\begin{array}{l}18.10 \\
\pm 3.2^{\mathrm{a}}\end{array}$ & $\begin{array}{c}950.64 \\
\pm 26.30^{\mathrm{a}}\end{array}$ & $\begin{array}{c}96.65 \\
\pm 13.0^{\mathrm{b}}\end{array}$ & $\begin{array}{c}837.40 \\
\pm 88.60^{\mathrm{a}}\end{array}$ & $\begin{array}{c}398.03 \\
\pm 22.30^{\mathrm{a}}\end{array}$ & $\begin{array}{c}109.70 \\
\pm 13.30^{\mathrm{a}} \\
\end{array}$ & $\begin{array}{c}364.70 \\
\pm 34.56^{\mathrm{a}}\end{array}$ & - & $\begin{array}{c}43.47 \\
\pm 5.66^{\mathrm{b}}\end{array}$ & $\begin{array}{c}3223.02 \\
\pm 460.30^{\mathrm{c}}\end{array}$ & $\begin{array}{c}120.5 \\
\pm 18.30^{\mathrm{a}}\end{array}$ \\
\hline July+Aug & $\begin{array}{c}7.70 \\
\pm 1.5^{\mathrm{b}} \\
\end{array}$ & - & - & - & $\begin{array}{l}98.20 \\
\pm 12.4^{\mathrm{c}}\end{array}$ & $\begin{array}{c}5122.0 \\
\pm 48.50^{\mathrm{c}}\end{array}$ & $\begin{array}{c}14.05 \\
\pm 0.56^{\mathrm{a}}\end{array}$ & $\begin{array}{c}3943.20 \\
\pm 506.60^{\mathrm{c}}\end{array}$ & $\begin{array}{c}1553.60 \\
\pm 460.30^{\mathrm{b}}\end{array}$ & $\begin{array}{c}158.02 \\
\pm 22.30^{\mathrm{b}}\end{array}$ & $\begin{array}{c}733.33 \\
\pm 68.55^{\mathrm{b}}\end{array}$ & $\begin{array}{c}23.50 \\
\pm 3.40^{\mathrm{a}}\end{array}$ & $\begin{array}{c}59.08 \\
\pm 8.50^{\mathrm{b}}\end{array}$ & $\begin{array}{c}2178.10 \\
\pm 544.05^{\mathrm{b}}\end{array}$ & $\begin{array}{c}250.2 \\
\pm 16.05^{\mathrm{b}}\end{array}$ \\
\hline Sep+Oct & - & - & - & - & $\begin{array}{l}31.04 \\
\pm 3.2^{\mathrm{b}}\end{array}$ & $\begin{array}{c}2300.20 \\
\pm 387.44^{\mathrm{b}}\end{array}$ & $\begin{array}{l}11.03 \\
\pm 0.5^{\mathrm{a}}\end{array}$ & $\begin{array}{c}1980.06 \\
\pm 136.30^{\mathrm{b}}\end{array}$ & $\begin{array}{c}1230.06 \\
\pm 408.80^{\mathrm{b}}\end{array}$ & $\begin{array}{c}746.04 \\
\pm 38.60^{\mathrm{c}}\end{array}$ & $\begin{array}{c}342.00 \\
\pm 18.80^{\mathrm{a}}\end{array}$ & $\begin{array}{c}683.60 \\
\pm 22.60^{\mathrm{b}}\end{array}$ & $\begin{array}{c}27.74 \\
\pm 5.30^{\mathrm{a}}\end{array}$ & $\begin{array}{c}642.56 \\
\pm 209.30^{\mathrm{a}}\end{array}$ & $\begin{array}{c}820.2 \\
\pm 39.60^{c}\end{array}$ \\
\hline
\end{tabular}

$\mathrm{N}=45$ for each season. The same letter is not significantly different $(\mathrm{P}<0.05)$, Gallic acid $(\mathrm{Ga})$, proto-catechuic acid (ProtoCat), p-OH benzoic acid (p-OH BA), catechin (Cat), vanillic acid(Va), caffeic acid(Caff), syringic acid (Syr), Epicatechin(EpCa), p-coumaric acid ( $p$-Cou), ferulic acid (Fer), rutin (Ru), daidzein (Dai)t-cinnamic acid ( $t$-Cinn), luteolin (Lut) and caffeic acid phenethyl ester (Cape).

A lot of research has been done in different countries about the change of propolis composition according to the season; in a study where Brazilian propolis was investigated monthly for a year; as a result of HPLC analysis, significant differences were detected in aromadendrin-4-methyl ether, baccharin andartepillin $\mathrm{C}$ values of propolis samples harvested at different times of the year. It was also determined that extracts with the highest antioxidant activity were detected on May, June and August productions (Simoes-Ambrosio et al. 2010). Salas et al. (2016) compared propolis samples which produced in Argentina in March and December, found no difference in antifungal and antibacterial performance of samples. In addition, it was found that Mexican propolis harvested over a four-month period did not show significant differences in phenolic and flavonoid values (Valencia et al. 2012). In a study which conducted in Poland; spring, summer and autumn propolis samples were compared in many respects. Although there was not determined significant difference on the chemical profile and antioxidant potential of propolis extracts obtained from these samples, but within the slight differences the highest values were determined in spring and the lowest values in autumn (Wozniak et al. 2019). The Season is an important factor determining propolis composition, since phenological factors influence biosynthesis of plant secondary metabolites. In addition to the seasonal changes and harvesting methods there is also honeybee race factor on propolis composition.

\section{Conclusions}

The results of the present study clearly revealed that honey bee races and different seasons have an effect on compound and connectedly on antioxidant property of the propolis. As we declared in our results; propolis samples which collected by different races and different seasons has also different antioxidant and radical scavenging activity due to their different compositions which shows us the medicinal value differences of the propolis. It was not surprised to see the effect of season on propolis composition but the race effect in the same apiary was gave us new information on propolis composition variables since there was no many studies on this area. Hence, propolis composition of each honey bee races and seasonal effect on propolis medicinal value should be studied by complex researches to clarify all the unanswered questions.

\section{Referances}

Al-Ghamdi A A, Al-Khaibari A M \& Omar M O M (2011). Effect of honeybee race and worker age on development and histological structure of hypopharyngeal glands of honeybee. Saudi Journal of Biological Sciences 18 (2):113-116 https://doi.org/10.1016/j.sjbs.2011.01.001

Baltas N, Karaoglu S A, Tarakci C \& Kolayli S (2016). Effect of propolis in gastric disorders: inhibition studies on the growth of Helicobacter pylori and production of its urease. J Enzyme Inhib Med Chem 31(2): 46-50 doi: 10.1080/14756366.2016.1186023.

Bankova V, Popova M \& Trusheva B (2006). Plant sources of propolis: An update from a chemist's point of view. Natural Product Communications 1(11):1023-1028, doi: 10.1177/1934578X0600101118

Benzie I F \& Strain J J (1996). The ferric reducing ability of plasma (FRAP) as a measure of "antioxidant power": the FRAP assay. Analytical biochemistry 239(1): 70-76 doi:10.1006/ABIO.1996.0292

Can Z, Yildiz O, Sahin H, Asadov E \& Kolaylı S (2015). Phenolic profile and antioxidant potential of propolis from Azerbaijan, Mellifera 15(1): 16-28

Da Cunha M G, Franchin M, de Carvalho Galvao L C, de Ruiz A L, de Carvalho J E, Ikegaki M, de Alencar S M, Koo H \& Rosalen P L (2013). Antimicrobial and antiproliferative activities of stingless bee Melipona scutellaris geopropolis. BMC Complement. Altern. Med. 13(23):2-9 doi: 10.1186/1472-6882/13/23 
Daugsch A, Moraes C S, Fort P \& Park Y K (2008). Brazilian red propolis--chemical composition and botanical origin. Evidence-based complementary and alternative medicine : eCAM 5(4): 435-441 doi.org/10.1093/ecam/nem057

Dutra R P, Abreu B V, Cunha M, Batista M C, Torres L M, Nascimento F R, Ribeiro M N \& Guerra R N (2014). Phenolic acids, hydrolyzable tannins, and antioxidant activity of geopropolis from the stingless bee Melipona fasciculata Smith. Journal of agricultural and food chemistry 62(12): 2549-2557 doi: 10.1021/jf404875v

Eroglu H E, Ozkul Y, Tatlisen A \& Silici S (2008). Anticarcinogenic and antimitotic effects of Turkish propolis and mitomycin-C on tissue cultures of bladder cancer. Natural product research 22(12): 1060-1066 doi: 10.1080/14786410802263972

Eroğlu N, Kambur Acar M, Kekeçoğlu M. (2021). The Investigation Propolis Foraging Preference of Different Honey Bee Races. Yuzuncu Yll University Journal of Agricultural Science Volume 31(1):133-141 doi: 10.29133/yyutbd.785911

Fukumoto L R \& Mazza G (2000). Assessing antioxidant and prooxidant activities of phenolic compounds. Journal of agricultural and food chemistry 48(8): 3597-3604 doi.org/10.1021/jf000220w

Gomez-Caravaca A M, Gomez-Romero M, Arraez-Roman D, Segura-Carretero A \& Fernandez-Gutierrez A (2006). Advances in the analysis of phenolic compounds in products derived from bees. Journal of pharmaceutical and biomedical analysis 41(4): 1220-1234 doi.org/10.1016/j.jpba.2006.03.002

Greenaway W, Scaysbrook T \& Whatley F R (1990). The Composition and Plant Origins of Propolis - a Report of Work at Oxford. Bee World 71(3): 107-118 doi.org/10.1080/0005772X.1990.11099047

Kekeçoğlu M, Eroğlu N, Kambur M, Uçak M. (2020). The Relationships Between Propolis Collecting Capability and Morphometric Features of Some Honey Bee Races and Ecotypes in Anatolia. Tarım Bilimleri Dergisi - Journal of Agricultural Sciences 26 (2020) 71-77 doi: 10.15832/ankutbd.447319

Kutluca S (2003). The effects of propolis production methods on colony performance and chemical properties of propolis. PhD Thesis, Atatürk University (Published), Turkey

Marcucci M C (1995). Propolis - Chemical-Composition, Biological Properties and Therapeutic Activity. Apidologie 26(2): 83-99 doi.org/10.1051/apido:19950202

Massaro F C, Brooks P R, Wallace H M \& Russell F D (2011). Cerumen of Australian stingless bees (Tetragonula carbonaria): gas chromatography-mass spectrometry fingerprints and potential anti-inflammatory properties. Die Naturwissenschaften 98(4): $329-337$ doi: 10.1007/s00114-011-0770-7

Massaro C F, Katouli M, Grkovic T, Vu H, Quinn R J, Heard T A, Carvalho C, Manley-Harris M, Wallace H M \& Brooks P (2014). Antistaphylococcal activity of C-methyl flavanones from propolis of Australian stingless bees (Tetragonula carbonaria) and fruit resins of Corymbia torelliana (Myrtaceae). Fitoterapia 95: 247-257 doi: 10.1016/j.fitote.2014.03.024.

Miguel M G \& Antunes M D (2011). Is propolis safe as an alternative medicine? Journal of pharmacy \& bioallied sciences 3(4): 479-495 doi: 10.4103/0975-7406.90101

Molyneux P (2004). The use of the stable free radical diphenylpicrylhydrazyl (DPPH) for estimating antioxidant activity Songklanakarin. $J$. Sci. Technol. 26 (2): 211-219

Ozkul Y, Silici S \& Eroglu E (2005). The anticarcinogenic effect of propolis in human lymphocytes culture. Phytomedicine 12(10): 742-747 doi: 10.1016/j.phymed.2004.06.015

Ruttner F (1988). Biogeography and Taxonomy of Honey Bee. Berlin: springer

Salas A L, Alberto M R, Zampini I C, Cuello A S, Maldonado L, Ríos J L, Schmeda-Hirschmann G \& Isla M I(2016) Biological activities of polyphenols-enriched propolis from Argentina arid regions. Phytomedicine 15;23(1):27-31 doi: 10.1016/j.phymed.2015.11.007.

Silici S \& Kutluca S (2005). Chemical composition and antibacterial activity of propolis collected by three different races of honeybees in the same region. Journal of ethnopharmacology 99(1): 69-73 doi: 10.1016/j.jep.2005.01.046

Simoes-Ambrosio L M C, Gregório L E, Sousa J P B, Figueiredo-Rinhel A S G, Azzolini A E C S, Bastos J K, \& Lucisano-Valim Y M (2010). The role of seasonality on the inhibitory effect of Brazilian green propolis on the oxidative metabolism of neutrophils. Fitoterapia 81(8): 1102-1108 doi: 10.1016/j.fitote.2010.07.008

Singleton V L, Orthofer R \& Lamuela-Raventós R M (1999). Analysis of total phenols and other oxidation substrates and antioxidants by means of folin-ciocalteu reagent. In Oxidants and Antioxidants Part A, 299:152-178 doi.org/10.1016/S0076-6879(99)99017-1

Şahinler N \& Gul A (2005). The effects of propolis production methods and honeybee genotypes on propolis yield. Pakistan Journal of Biological Sciences 8(9): 1212-1214 doi: 10.3923/pjbs.2005.1212.1214

Teixeira E W, Negri G, Meira R M, Message D \& Salatino A (2005). Plant Origin of Green Propolis: Bee Behavior, Plant Anatomy and Chemistry. Evidence-based complementary and alternative medicine : eCAM, 2(1): 85-92 doi: 10.1093/ecam/neh055

Uzel A, Sorkun K, Oncag O, Cogulu D, Gencay O \& Salih B (2005). Chemical compositions and antimicrobial activities of four different Anatolian propolis samples. Microbiological research, 160(2): 189-195 doi: 10.1016/j.micres.2005.01.002

Valencia D, Alday E, Robles-Zepeda R, Garibay-Escobar A, Galvez-Ruiz J C, Salas-Reyes M \& Velazquez C (2012). Seasonal effect on chemical composition and biological activities of Sonoran propolis. Food Chemistry, 131(2): 645-651 doi.org/10.1016/j.foodchem.2011.08.086

Wilson M B, Spivak M, Hegeman A D, Rendahl A, Cohen J D (2013) Metabolomics Reveals the Origins of Antimicrobial Plant Resins Collected by Honey Bees. PLoS ONE 8(10): e77512 https://doi.org/10.1371/journal.pone.0077512

Wozniak M, Mrówczyńska L, Waśkiewicz A, Rogoziński T \& Ratajczak I (2019). The role of seasonality on the chemical composition, antioxidant activity and cytotoxicity of Polish propolis in human erythrocytes. Brazilian Journal of Pharmacognosy, 29(3): 301-308 doi.org/10.1016/j.bjp.2019.02.00르

C 2021 by the authors. Licensee Ankara University, Faculty of Agriculture, Ankara, Turkey. This article is an open access article distributed under the terms and conditions of the Creative Commons Attribution (CC BY) license (http://creativecommons.org/licenses/by/4.0/). 